RYSZARD SELEJDAK, RZYM

\title{
POSŁUGA LITURGICZNA DIAKONÓW STAŁYCH
}

Wymiar liturgiczny stanowi jeden z trzech podstawowych wymiarów posługi diakonów stałych, wspomnianych przez II Sobór Watykański w Konstytucji dogmatycznej o Kościele Lumen gentium. ${ }^{1}$ Ojciec Święty Jan Paweł II wyjaśnia, że „Diakon jest (...) uświęcającym, gdyż udziela sakramentu chrztu (...), sprawuje sakramentalia, uczestniczy w celebracji Mszy św. w charakterze «sługi krwi», przechowuje oraz rozdziela Eucharystię". ${ }^{2}$ Diakoni są powołani do służenia i asystowania biskupom i prezbiterom, którzy przewodniczą wszelkiej liturgii, strzegą doktryny i kierują Ludem Bożym. Wypełniając swoją liturgiczną posługę, winni oni „współpracować w budowaniu jedności chrześcijan bez uprzedzeń i bez niewłaściwych inicjatyw". 3

\section{Diakonia liturgiczna - charakterystyka ogólna}

Diakonia liturgiczna diakona stałego, wypływająca z sakramentu święceń, różni się zasadniczo od każdej innej posługi liturgicznej,

1 Por. S o bó r W a t y k ań s k i II, „Lumen gentium”. Konstytucja dogmatyczna o Kościele, 21 XI 1964, w: Sobór Watykański II, Konstytucje, Dekrety, Deklaracje, Poznań 2002, nr 29 (dalej: KK).

2 Jan Pawe 1 II, Discorso ai diaconi permanenti in Italia, 16 III 1985, nr 2, Insegnamenti 8 (1985) 1, s. 649 (tłum. własne); por. KK. nr 29; Kodeks Prawa Kanonicznego, Poznań 1983 (dalej: KPK), kan. 1008; K o n g r e g a c j a d s. D u c how i eń s t w a, Dyrektorium o posłudze $i$ życiu diakonów stałych, 22 II 1998, Watykan 1998 (dalej: DPŻDS), nr 22.

3 Papieska Rada ds. Popierania Jedności Chrześcijan, Dyrektorium o aplikacji Zasad i Norm Ekumenicznych, 25 III 1993, Acta Apostolicae Sedis 85/1993 (dalej: AAS), s. 1068; por. także, Kongrega c j N a u k W i a ry, List Communionis notio, 28 V 1992, AAS 85/1993, s. 838; DPŻDS, nr 22. 
którą duszpasterze mogą powierzyć wiernym nie mającym świeceń. Różni się ona także od posługi kapłańskiej. ${ }^{4}$

W ofierze eucharystycznej, diakon nie sprawuje tajemnic, ale, z jednej strony, reprezentuje czynnie wierny Lud Boży, pomagając mu w specyficzny sposób złączyć dar swego życia z ofiarą Chrystusa, z drugiej zaś, służy w imieniu samego Chrystusa, pomnażając owoce Jego ofiary za pośrednictwem Kościoła. ${ }^{5}$

Jako że „liturgia jest jednak szczytem, do którego zmierza działalność Kościoła, i zarazem jest źródłem, z którego wypływa cała jego moc", ${ }^{6}$ ten przywilej konsekracji diakońskiej stanowi również źródło łaski sakramentalnej zasilającej całą posługę. ${ }^{7}$

Diakon, sprawując posługę liturgiczną, powinien być świadomy, że „każda celebracja liturgiczna jako działanie Chrystusa-Kapłana i Jego Ciała, czyli Kościoła, jest czynnością w najwyższym stopniu świętą, której skuteczność $\mathrm{z}$ tego samego tytułu i w tym samym stopniu nie posiada żadna inna czynność Kościoła". ${ }^{8}$ Skuteczność liturgii nie opiera się na świętości posługi, ale pochodzi od Chrystusa Zbawiciela. Prawda ta winna czynić diakona pokornym, by nigdy nie narażał na ryzyko dzieła Chrystusa. Jednocześnie winna skłaniać go do świętości życia oraz do tego, by starał się być godny posługi liturgicznej. ${ }^{9}$ Czynności liturgiczne, należące do Kościoła, nie mogą być sprowadzane do czynności o charakterze prywatnym lub

4 Por. KK, nr 29; DPŻDS, nr 28; A. B o r r a s, Il diaconato, vittima della sua novità. Appunti sul diaconato, La Rivista del Clero Italiano 5/2008, s. 334; R. S e le j d a k, Tożsamość, duchowość, formacja i posługa diakonów stałych, Częstochowa 2003, s. 107; t e n ż e, Diakonat stały w świetle dokumentów Soboru Watykańskiego II, posoborowego Urzędu Nauczycielskiego Kościoła i narodowych „Rationes institutionis diaconorum permenentium”, Warszawa 2010, s. 297.

5 Por. DPŻDS, nr 28.

6 S o bó r Wa ty k án s k i II, „Sacrosanctum Concilium”. Konstytucja o liturgii świętej, 4 XII 1963, w: Sobór Watykański II, Konstytucje, Dekrety, Deklaracje, nr 7 (dalej: KL).

7 Por. DPŻDS, nr 28.

$8 \mathrm{KL}, \mathrm{nr} 7$.

9 Por. DPŻDS, nr 29. 
społecznym, które może każdy celebrować według swego uznania. ${ }^{10}$ Dlatego diakon jest zobowiązany do przestrzegania przepisów odnoszących się do świętych tajemnic z taką pobożnością, by prowadzić Kościół do uświęcania oraz pociągać swoją postawą wiernych do udziału w kulcie w sposób świadomy i pogłębiać ich wiarę przez oddawanie coraz większej czci Bogu. ${ }^{11}$

Według kan. $835 \S 3$ KPK, „diakoni mają udział w sprawowaniu kultu Bożego, zgodnie z przepisami prawa”. Katechizm Kościoła Katolickiego stwierdza zaś, że do diakonów należy ,asystowanie biskupowi i prezbiterom przy celebracji Boskich misteriów". ${ }^{2}$ Diakoni winni więc zabiegać o szerzenie kultu obejmującego całą wspólnotę, troszczyć się o wewnętrzne zaangażowanie wszystkich wiernych i włączać się w sprawowanie różnych posług. ${ }^{13}$

Powinni oni działać w taki sposób, by ich służba przy ołtarzu ukazywała zasadniczy związek między kultem a wspólnotą apostolską, między liturgią a diakonią całego Ludu Bożego. Diakoni razem z biskupami mają być gwarantami autentyczności ewangelicznej kultu chrześcijańskiego. ${ }^{14}$

Przez sprawowanie ,diakonii liturgicznej” diakoni winni nieustannie przechodzić z życia liturgicznego do profanum i odwrotnie. Relacja ta ma przemieniać liturgię „rytualną” w liturgię ,życia”. W osobie diakona liturgia i służba powinny być postrzegane jako akt człowieka ukierunkowującego swoje codzienne życie ku Bogu. Jego

10 Por. KL, nr 22 ; KPK, kan. 841, 846.

11 Por. tamże, kan. 840; DPŻDS, nr 29; A. A $1 \mathrm{t}$ a $\mathrm{n}$ a, La restaurazione del diaconato permanentne nella Chiesa italiana, Il diaconato in Italia 11/1972, s. 7-8; R. S e l e j d a k, Diakonat stały w świetle dokumentów Soboru Watykańskiego II, posoborowego Urzędu Nauczycielskiego Kościoła i narodowych „Rationes institutionis diaconorum permenentium”, s. 298.

12 Katechizm Kościoła Katolickiego, Poznań 1994, nr 1570 (dalej : KKK).

13 Por. KL, nr 26-27.

14 Por. A. B o r r a s, Il diaconato, vittima della sua novità? s. 334; R. S e 1 e j d a k, Diakonat staty w świetle dokumentów Soboru Watykańskiego II, posoborowego Urzędu Nauczycielskiego Kościoła i narodowych „Rationes institutionis diaconorum permenentium", s. 298. 
obecność ma się stawać „łącznikiem” między światem i Kościołem, redukując również ewentualny dystans między świeckimi a hierarchią. Ponadto obecność diakona podczas celebracji Eucharystii winna promować proces aktualizacji posług całego zgromadzenia.

Diakon jest zatem wezwany do czuwania nad stylem sprawowania liturgii, jak i nad swoim postępowaniem, aby wszyscy członkowie zgromadzenia odnaleźli głęboki sens własnego uczestnictwa i by urzeczywistniały się mocne i głębokie związki między wszystkimi. Jest to zadanie, niezwykle subtelne i długotrwałe, wymagające od diakona ogromnej cierpliwości. ${ }^{15}$

Ponadto diakon winien mieć na uwadze wymiar estetyczny czynności liturgicznych, umożliwiający człowiekowi odczuć piękno tego, co jest sprawowane. Muzyka i śpiew, nawet gdy są ubogie i proste, słowo głoszone oraz wspólnota wiernych, przeżywających pokój i przebaczenie Chrystusa, stanowią drogocenne dobro, o wzrost którego ma on właśnie się zatroszczyć. ${ }^{16}$

Sprawując diakonię liturgii, diakoni są wezwani do wiernego przestrzegania obowiązujących przepisów liturgicznych. Nie mogą z własnej inicjatywy niczego dodawać, pomijać lub zmieniać ${ }^{17}$. Wszelkie manipulacje liturgią są równoznaczne z pozbawianiem zawartego w niej bogactwa tajemnicy Chrystusa. W związku z tym diakoni winni ograniczyć się do sprawowania tylko tego, co należy do ich kompe tencji. ${ }^{18}$ Mają też obowiązek noszenia z godnością odpowiednich szat liturgicznych. ${ }^{19}$ Strój liturgiczny diakona stanowią:

15 Por. E. P e trol in o, Diakoni, zwiastuni Słowa Bożego, szafarze ołtarza i miłosierdzia, Kraków 2002, s. 45-46; R. S e l e j d a k, Diakonat stały w świetle dokumentów Soboru Watykańskiego II, posoborowego Urzędu Nauczycielskiego Kościoła i narodowych ,, Rationes institutionis diaconorum permenentium”, s. 298.

16 Por. DPŻDS, nr 30.

17 Por. KPK, kan. $846 \S 1$.

18 Por. KL, nr 28.

19 Por. KPK, kan. 929. 
dalmatyka, używana w różnych i odpowiednich kolorach liturgicznych, pasek i stuła. ${ }^{20}$

\section{Posługi liturgiczne diakona stałego - charakterystyka szczegółowa}

Według Konstytucji dogmatycznej o Kościele Lumen gentium, diakonia liturgii sprowadza się do: uroczystego udzielania chrztu; przechowywania i rozdzielania Eucharystii; asystowania i błogosławienia w imieniu Kościoła związków małżeńskich; zanoszenia Wiatyku umierającym; przewodniczenia nabożeństwom i modlitwie wiernych; udzielania sakramentaliów; przewodniczenia obrzędom żałobnym i pogrzebowym. ${ }^{21}$

Posługi liturgiczne powierzone diakonowi wspomina również motu proprio Pawła VI Sacrum diaconatus ordinem. Dokument ten do zakresu diakoni liturgii zalicza: asystowanie biskupowi i kapłanowi przy sprawowaniu czynności liturgicznych; uroczyste udzielanie chrztu; przechowywanie Eucharystii, udzielanie Komunii św. sobie i innym, zanoszenie jej jako Wiatyku umierającym i udzielanie ludowi eucharystycznego błogosławieństwa puszką; udzielanie sakramentaliów oraz przewodniczenie obrzędom pogrzebowym; czytanie wiernym Pisma Świętego oraz nauczanie i zachęcanie ludu.

W zastępstwie kapłana, a więc tylko w przypadku jego braku, do zadań liturgicznych diakona należy: asystowanie przy zawieraniu małżeństwa i błogosławienie związku w imieniu Kościoła; przewodniczenie kultowi religijnemu i modlitwom. ${ }^{22}$

Powyższe zestawienie funkcji liturgicznych diakonów dowodzi, że motu proprio Pawła VI niemal dosłownie powtarza rozdział 29

20 Pontyfikat Rzymski. Obrzędy święceń biskupa, prezbiterów i diakonów, Katowice 1998, nr 188, s. 120: „Bezpośrednio po modlitwie święceń wyświęceni nakładają stułę w sposób właściwy diakonom oraz dalmatykę, będące zewnętrznym znakiem posługi, którą odtąd będą pełnić w liturgii”; por. DPŻDS, nr 30.

21 Por. KK, nr 29.

22 Por. P a w e 1 VI, Motu proprio „, Sacrum diaconatus ordinem”, 18 VI 1967, V, 22, AAS 59/1967, s. 701-702. 
Konstytucji Lumen gentium. Ponadto należy zauważyć, że wspomniane motu proprio interpretuje restrykcyjnie asystowanie i błogosławienie przez diakona małżeństwa oraz przewodniczenie kultowi religijnemu i nabożeństwom, wprowadzając klauzulę „w przypadku braku kapłana". ${ }^{23}$

Funkcje liturgiczne diakona wspomina także list okólny Kongregacji Edukacji Katolickiej Come è a conoscenza. Dokument ten podkreśla, że do diakona należy przede wszystkim udzielanie Wiatyku i przewodniczenie liturgii Słowa Bożego. ${ }^{24}$

Wreszcie Kongregacja ds. Duchowieństwa w Dyrektorium o postudze i życiu diakonów stałych, do diakonii liturgii diakona stałego zalicza: udzielanie chrztu; asystowanie biskupowi lub kapłanowi przy sprawowaniu Eucharystii; sprawowanie sakramentu małżeństwa poza mszą św. oraz udzielanie błogosławieństwa ślubnego w imieniu Kościoła; sprawowanie sakramentaliów; przewodniczenie nabożeństwom żałobnym odprawianym bez mszy św., jak też przewodniczenie obrzędowi pogrzebu i pochówku. ${ }^{25}$

\section{Chrzest}

Zgodnie z łacińską tradycją kościelną, w przypadku konieczności, każdy człowiek może udzielić chrztu jako szafarz nadzwyczajny. Tradycję tę streszcza przepis Dekretu dla Armeńczyków Soboru Florenckiego, który mówi: „Szafarzem sakramentu chrztu

23 Por. S. Z a r d o n i, I diaconi nella Chiesa. Ricerca storica e teologica sul diaconato, Bologna 1991², s. 57-58; R. S e 1 e j d a k, Diakonat stały w świetle Biblii i historii Kościoła, Częstochowa 2002, s. 107; t e n ż e, Tożsamość, duchowość, formacja i posługa diakonów stałych, s. 108; t e n ż e, Diakonat stały w świetle dokumentów Soboru Watykańskiego II, posoborowego Urzędu Nauczycielskiego Kościoła i narodowych „, Rationes institutionis diaconorum permenentium”, s. 300.

${ }^{24}$ Por. Kongrega cja Edukacji Katoli ckiej, Lettera circolare ai Rev.mi Rappresentanti Pontifici „Come è a conoscenza” sulla formazione dei candidati al diaconato permanente, Prot. N. 137/69, 16 VII 1969, EV 3/1968-1970, s. 835 .

25 Por. DPŻDS, nr 31-36. 
jest kapłan, którego upoważnia do chrzczenia sprawowany urząd. W przypadku konieczności, jednakże, nie tylko kapłan czy diakon może chrzcić, ale także osoba świecka, mężczyzna lub kobieta, również poganin i heretyk, o ile zastosuje przyjętą formę Kościoła, i zamierza uczynić to, co czyni Kościół". ${ }^{26}$

Ojcowie Kościoła w swoich pismach ukazują często diakonów towarzyszących biskupowi lub prezbiterowi podczas udzielania tego sakramentu. Hipolit w Tradycji Apostolskiej wspomina, że diakon towarzyszy biskupowi i prezbiterom w czasie chrztu, trzymając olej dziękczynienia i olej egzorcyzmu oraz schodząc do wody razem z chrzczonym: „O godzinie wyznaczonej na chrzest biskup odmówi modlitwę dziękczynną nad olejem i napełni nim naczynie: będzie to olej dziękczynienia (Eucharystia). Następnie nad innym olejem odmówi egzorcyzmy: będzie to olej egzorcyzmu. $Z$ kolei jeden z diakonów weźmie olej egzorcyzmu i stanie po lewej stronie prezbitera, drugi zaś diakon weźmie olej dziękczynienia i stanie po prawej stronie prezbitera. Prezbiter, odprowadzając na bok każdego z osobna kandydata, poleci mu zwrócić się ku zachodowi i wymawiać następujące słowa: «Wyrzekam się ciebie, szatanie, i wszelkiego przepychu twego i wszelkich dzieł twoich»; po tym wyrzeczeniu namaści go olejem egzorcyzmu, mówiąc: «Niech odejdzie od ciebie wszelki zły duch». Następnie przekaże go wstępującemu do niej towarzyszył". ${ }^{27}$

26 S obór Flore n c k i, Bulla „Exultate Deo”, w: H. D e n zi nge r, A. H ü n e r m a n n, Enchiridion symbolorum, definitionum et declarationum de rebus fidei et morum, Bologna 1996², s. 546 (tłum. własne).

${ }_{27} \mathrm{H}$ i p ol it R z y m s k i, La Tradition Apostolique, Sources chrétiennes, t. 11 bis (dalej: SCh), s. 82 (tłum. własne). 
Diakonów wspomagających biskupów i prezbiterów w czynnościach liturgicznych związanych z udzielaniem chrztu wspominają także Tertulian ${ }^{28}$ i Cyprian. ${ }^{29}$

Kodeks Prawa Kanonicznego stwierdza, że diakon jest obok biskupa i prezbitera zwyczajnym szafarzem sakramentu chrztu. ${ }^{30}$.

Motu proprio Pawła VI Sacrum diaconatus ordinem mówi zaś, że diakon ma władzę ,udzielania chrztu uroczystym obrzędem oraz uzupełnienia opuszczonych ceremonii w odniesieniu do ochrzczonego dziecka lub dorosłego". ${ }^{31}$

W Obrzędach chrześcijańskiego wtajemniczenia dorostych podkreśla się, że jeśli są do dyspozycji diakoni, to powinni być oni gotowi do służby katechumenatowi. Zachęca się nawet Konferencje Episkopatów, które wprowadziły diakonat stały, by zatroszczyły się o odpowiednią liczbę diakonów do przeprowadzenia katechumenatu według stopni i okresów wszędzie tam, gdzie wymagają tego potrzeby duszpasterskie. ${ }^{32}$ Diakoni powinni współpracować i pełnić służbę podczas przygotowania do chrztu..$^{33}$ Ponadto mogą oni udzielać tego sakramentu za zgodą biskupa, a w każdym razie winni służyć pomocą podczas obrzędu, wykonując takie czynności, jak: przedstawienie kandydatów; ${ }^{34}$ celebracja obrzędu egzorcyzmu; $;{ }^{35}$ wezwanie wybranych do przekazania Symbolu wiary ${ }^{36}$ i Modlitwy

28 Por. Te r tulia n, De baptismo, 17, 1-2, Corpus Christianorum. Series Latina (dalej: CCL) 1, 291; por. także, P. M a t t e i, Habere ius sacerdotis. Sacerdoce laïcat au témoignage de Terullien „De exhortatione castitatis” et „De monogamia”, Recherches de science religieuse 59/1985, s. 200-221; H. W ó j t o w i c z, Terminologia kapłańska u Tertuliana, Vox Patrum 13-15 (1993-1995) 24-29, s. 77-78, 82.

29 Por. C y pri a n, Epistula 5, 2, 2, CCL III B, 28; t e n ż e, Epistula 17, 2, 2, CCL III B, 97-98.

30 Por. KPK, kan. $861 \S 1$.

31 P a w e 1 VI, Motu proprio „, Sacrum diaconatus ordinem”, V, 22, 2, s. 702.

32 Por. Obrzędy chrześcijańskiego wtajemniczenia dorosłych, Katowice 1988, nr 47.

33 Por. tamże, nr 19.

34 Por. tamże, nr 143.

35 Por. tamże, nr 156.

36 Por. tamże, nr 186. 
Pańskiej; ${ }^{37}$ namaszczenie katechumenów krzyżmem świętym ${ }^{38}$ i udzielanie chrztu, ${ }^{39}$ jeśli są liczni wybrani. ${ }^{40}$

Kodeks Prawa Kanonicznego zarządza, że udzielanie chrztu przez diakona, poza wypadkiem konieczności, ${ }^{41}$ wymaga pozwolenia udzielonego przez proboszcza, który jest odpowiedzialny za chrzest swoich parafian. ${ }^{42}$

Zdaniem S. Zardoni, diakoni winni udzielać chrztu z wielką radością. Jest to bowiem sakrament Chrystusa, czyniący Jego Kościół świętym przez oczyszczenie „obmyciem wodą, któremu towarzyszy słowo” (Ef 5, 26). Chrzest wprowadza wiernego „przez obmycie odradzające i odnawiające w Duchu Świętym" (Tt 3, 5) w śmierć i zmartwychwstanie Chrystusa oraz czyni z niego nowe stworzenie przeznaczone do nowego życia (por. Rz 6, 4). ${ }^{43}$

Ponadto diakoni winni czuć się odpowiedzialni za tych, których duchowo przez chrzest i naukę zrodzili (por. 1Kor 4, 15; 1P 1, 23), troszcząc się o nich jako ich ojcowie w Chrystusie. ${ }^{44}$ Szafarz bowiem nie jest „dystrybutorem” sakramentów. Nie daje chrztu, lecz chrzci. Nie rozdaje rzeczy świętej, lecz wykonuje czynność angażującą całą jego osobę i osobowość. Diakon udzielający chrztu jest znakiem Chrystusa. W konsekwencji, staje się on dla osoby ochrzczonej duchowym ojcem, który kocha, cieszy się i troszczy się o swoje dziecko: „Dzieci moje, oto ponownie w bólach was rodzę, aż Chrystus w was się ukształtuje" (Ga 4, 19). Chrzest jest bowiem tylko początkiem

37 Por. tamże, nr 191.

38 Por. tamże, nr 224.

39 Por. tamże, nr 220.

40 Por. tamże, nr 222.

41 Por. KPK, kan. 862.

42 Por. tamże, kan. 530, $1^{\circ}$.

43 Por. S. Z a r d o n i, I diaconi nella Chiesa, s. 130; R. S e le j d a k, Diakonat staty $w$ świetle dokumentów Soboru Watykańskiego II, posoborowego Urzędu Nauczycielskiego Kościoła i narodowych „Rationes institutionis diaconorum permenentium»", s. 302.

44 Por. KK, nr 28. 
drogi, która ma zaprowadzić wiernego „do człowieka doskonałego, do miary wielkości według Pełni Chrystusa” (Ef 4, 13).

Diakoni powołani i posłani do wykonywania posługi Słowa moga w tych, którzy są otwarci na działanie Ducha Świętego, wzbudzić nawrócenie i wiarę, a więc doprowadzić ich do przyjęcia chrztu włączającego w Kościół, mistyczne Ciało Chrystusa. Działanie to, $\mathrm{z}$ jednej strony, pociąga za sobą odpowiedzialność diakonów za dojrzałość chrześcijańską „,wiernych, których duchowo przez chrzest (...) zrodzili”, ${ }^{45} \mathrm{z}$ drugiej zaś strony, zależność i wspólnotę z urzędem biskupa, który, podobnie jak apostołowie udzielający Ducha ochrzczonym przez Filipa w Samarii (por. Dz 8, 11-18), może umocnić w Chrystusie (por. 2Kor 1,21) ochrzczonych przez sprawujących urząd diakonatu. Działanie to pociąga za sobą zależność i wspólnotę z urzędem prezbitera, który czyni Chrystusa obecnym w Eucharystii, by ochrzczony i bierzmowany mógł posilać się Ciałem i Krwią Chrystusa i trwać w Chrystusie, a Chrystus w nim (por. J 6,56$){ }^{46}$

\section{Eucharystia}

Jezus Chrystus podczas Ostatniej Wieczerzy ustanowił Eucharystyczną Ofiarę Ciała i Krwi swojej, by w niej na całe wieki, aż do swego powtórnego przyjścia, utrwalić ofiarę krzyża i Kościołowi powierzyć pamiątkę swej męki i zmartwychwstania. Eucharystia stanowi dla każdego chrześcijanina sakrament miłosierdzia, znak jedności, węzeł miłości, ucztę paschalną, w której pożywa Chrystusa, a jego dusza napełnia się łaską i otrzymuje zadatek przyszłej chwały. ${ }^{47}$ Dlatego wszyscy ochrzczeni są wezwani do uczestnictwa

45 Tamże.

46 Por. S. Z a r d o n i, I diaconi nella Chiesa, s. 130; R. S e l e j d a k, Diakonat staty $w$ świetle dokumentów Soboru Watykańskiego II, posoborowego Urzędu Nauczycielskiego Kościoła i narodowych „,Rationes institutionis diaconorum permenentium", s. 303.

47 Por. KL, nr 47. 
w Eucharystii „świadomie, pobożnie i czynnie (...), ofiarując niepokalaną Hostię nie tylko przez ręce kapłana, lecz także razem z nim". 48

II Sobór Watykański w Dekrecie o posłudze i życiu prezbiterów Presbyterorum ordinis stwierdza, że „wszystkie kościelne posługi i dzieła apostolstwa, wiążą się ze świętą Eucharystią i ku niej zmierzają". ${ }^{49}$ Dlatego też służebność Kościoła w szczególny sposób wyraża się w Liturgii Eucharystii. W niej bowiem „każdy z uczestników zgromadzenia eucharystycznego ma prawo i obowiązek wnieść wkład we wspólne uczestnictwo, w zależności od stopnia święceń i od spełnianej funkcji (...), aby w ten sposób w samym porządku akcji liturgicznej ukazywał się Kościół ze swą strukturą różnych święceń i posług". ${ }^{50}$

Nawiązanie do powyższego stwierdzenia w Ogólnym wprowadzeniu do Mszału rzymskiego, diakonowi poświęca się dość sporo uwagi. W związku z funkcjami związanymi z wyższymi święceniami zauważa się, że wśród usługujących pierwsze miejsce zajmuje diakon, otaczany od samego początku Kościoła „wielkim szacunkiem”. ${ }^{51}$ Prawdę tę potwierdza niezwykle bogata literatura patrystyczna.

Pierwsza wzmianka o diakonach posługujących biskupowi w czasie sprawowania Eucharystii znajduje się w Didaché. ${ }^{52}$

W 314 r. na Synodzie w Arles pojawiła się niepokojąca wiadomość o diakonach, którzy w czasie sprawowania Eucharystii przekraczali swoje kompetencje i wykonywali posługę zarezerwowaną ściśle prezbiterom: „Dotarło do nas, iż w wielu miejscach diakoni celebrują

48 Tamże, nr 48.

49 S obó r Wa ty k án s k i II, „Presbyterorum ordinis” Dekret o postudze i życiu prezbiterów, 7 XII 1965, w: Sobór Watykański II, Konstytucje, Dekrety, Deklaracje (dalej: DP), nr 5.

50 Ogólne wprowadzenie do Mszału rzymskiego, w: Mszał rzymski dla diecezji polskich, Poznań 1986 (dalej: OWMR), nr 58.

51 Tamże, nr 61.

52 Por. Didaché, XIV, 1 - XV, 1, Patres Apostolici (dalej: PA) I, 33-34. 
Eucharystię (offerre): zdecydowano więc, że w przyszłości w żadnym przypadku nie może się to powtórzyć". ${ }^{33}$

Tego typu przypadki należały jednak do rzadkości. Diakon towarzyszył zwykle biskupowi i prezbiterowi nie tylko jak szafarz Komunii św., ale również jako głosiciel Ewangelii i ten, który był powołany do czuwania nad godnym, uważnym i pobożnym celebrowaniem świętych tajemnic. Dlatego też był nazywany koncelebrantem. ${ }^{54}$

Wymowne świadectwo dają temu Konstytucje Apostolskie. Według nich, odpowiednia liczba diakonów stanowi najlepszą gwarancję tego, by liturgia mszy św. była sprawowana z zachowaniem właściwego porządku. Diakon uroczyście odczytuje Ewangelię, ${ }^{55}$ zaprasza wiernych do pozdrowienia się świętym pocałunkiem („duchowni niech całują biskupa, świeccy mężczyźni świeckich, a niewiasty niechaj całują niewiasty") ${ }^{56}$ przed Modlitwą Eucharystyczną prosi katechumenów, niewiernych i innowierców, by opuścili wspólnotę; ${ }^{57} \mathrm{~W}$ odpowiedni sposób zachęca matki, by przygarnęły do siebie dzieci. ${ }^{58}$ Do diakona należy również modlitwa wiernych, przewodniczenie wiernym w ,dziękczynieniu” po komunii św. ${ }^{59}$ oraz rozwiązanie zgromadzenia. ${ }^{60}$ Diakon czuwa też przy drzwiach kościoła, ażeby nikt nie wchodził i wychodził w czasie Modlitwy Eucharystycznej; ${ }^{61}$ nie spuszcza z oczu dzieci, siedzących na schodach, by nie czyniły zamieszania; ${ }^{62}$,inni natomiast diakoni mają się przechadzać i obserwować mężczyzn i kobiety, aby nikt się nie wiercił, nie szeptał, nie

53 Kan. 15, Sacrorum conciliorum nova et amplissima collectio (dalej: Mansi) II, 473 (tłum. własne).

54 Por. G i ova n n i C r i s o s t o m o, Divina Liturgia, Roma 1967, s. 125; por. N. C e c i, Il ministero del diacono nel mondo del lavoro, Roma 1999, s. 38.

55 Por. Constitutiones Apostolorum, VIII, 4, 6-8, Didascalia et Constitutiones Apostolorum (dalej: DCA) I, 473-477.

56 Tamże, VIII, 11, 7-9, DCA I, 495 (tłum. własne).

57 Por. tami̇e, VIII, 12, 2, DCA I, 495.

58 Por. tamże.

59 Por. tamże, VIII, 14, 1-3, DCA I, 519.

${ }^{60}$ Por. tamie, VIII, 15, 10, DCA I, 521.

${ }_{61}$ Por. tamie, VIII, 11, 11, DCA I, 495.

62 Por. tamże, VIII, 11, 10, DCA I, 495. 
drzemał". ${ }^{63}$ Ponadto należy do nich przynoszenie darów na ołtarz. ${ }^{64}$ Dwaj zaś diakoni, stojący po obydwu stronach ołtarza, zobowiązani są do trzymania wachlarza i łagodnego nim poruszania w taki sposób, by „małe fruwające stworzonka nie wpadły do kielicha”. ${ }^{65}$

Podobną rolę diakonów w czasie sprawowania Eucharystii opisują też Kanony Apostolskie. Diakon ukazuje ludowi kielich w sposób mniej uroczysty, niż to czynią kapłani ${ }^{66} \mathrm{~W}$ czasie mszy św., połączonej z udzielaniem sakramentu chrztu, diakon asystujący biskupowi sprawuje pieczę nad olejami. Był on też odpowiedzialny za doprowadzenie katechumenów do wody chrzcielnej. Wypowiadał przy tym słowa: „Czy wierzysz w Jedynego Boga, Ojca Wszechmogącego i Jego Syna Jezusa Chrystusa, naszego Zbawiciela, i Jego Ducha Świętego, który ożywia wszelkie stworzenie - Trójcę równą we wszystkich Osobach, Jedynego co do natury Boga, jedyną Zwierzchność, jedyne królestwo, jedną wiarę, jeden chrzest w Kościele powszechnym, życie wieczne. Amen?"67

Diakon odbierał także odpowiedź katechumena na to wyznanie wiary. Po chrzcie przynosił na ołtarz chleb, wino, oliwę i kadzidło składane przez wiernych biskupowi. Jeżeli we mszy tej nie uczestniczyli kapłani, zadaniem diakona było rozdawanie Komunii św. pod dwiema postaciami. Ponadto diakon przynosił dary ofiarne podczas innych uroczystych mszy św., jak np. podczas udzielania sakry biskupiej. ${ }^{68}$ Wtedy też trzymał otwarty ewangeliarz nad głową przyjmującego święcenia. Po lekturze Ewangelii stawał na stopniach i głośno wołał: „Niech nikt z niewierzących nie pozostaje odtąd w tym miejscu!" 69

63 Tamże (tłum. własne).

64 Por. tamże, VIII, 12, 3, DCA I, 495-497.

65 Tamże, VIII, 12, 3, DCA I, 497 (tłum. własne).

66 Por. Les 127 Canons des Apôtres, I, kan. 57, Patrologia Orientalis (dalej: POr) 8, 641-642.

${ }^{67}$ Tamże, I, kan. 34, POr 8, 603-604 (tłum. własne).

68 Por. tamże, kan. 21, POr 8, 590-591.

69 Tamże, I, kan. 52, POr 8, 634 (tłum. własne). 
W momencie, gdy biskup kończył modlitwę powszechną, diakon ponownie głośno wzywał wiernych: „Przekażcie sobie święty pocałunek!" 70

W czasie sprawowania Eucharystii diakoni gromadzili dzieci wokół ambony, gdzie jeden z nich opiekował się nimi. Inni zaś chodzili po kościele, przypominając wiernym potrzebę godnego zachowania. Strzegli oni też wejścia dla mężczyzn, uniemożliwiając wstęp nieochrzczonym oraz powstrzymując chętnych do wychodzenia w czasie, gdy wymagane było szczególne skupienie. ${ }^{71}$

Przed ofiarowaniem diakon, zwracając się do wiernych wypowiadał następującą zachętę: „Niech żaden katechumen nie pozostaje tutaj, ani nikt z nauczanych, niewiernych, ani żaden heretyk! Kobiety, powstrzymajcie od tego swe dzieci. Niech nikt nie chowa urazy względem bliźniego, niech nie żywi w sercu hipokryzji. Bądźcie pokorni przed Panem. Przystępujemy w prostocie i z bojaźnią!"72

Przed końcowym błogosławieństwem wzywał wiernych: „Skłońcie głowy przed Panem, by was pobłogosławił" oraz rozwiązywał zgromadzenie, mówiąc: „Idźcie w pokoju!"73

W V w. posługę homiletyczną diakonów w czasie Eucharystii wspomina Cezary z Arles. ${ }^{74}$ Według niego, znajomość Pisma Świętego jest warunkiem nie tylko właściwego głoszenia homilii, ale udzielenia święceń diakonatu. Cezary domagał się, by kandydat na diakona „co najmniej cztery razy przeczytał Pismo Święte”. 75

Wracając do Ogólnego wprowadzenia do Mszału rzymskiego, zauważa się, że do posług właściwych diakonowi podczas celebracji

70 Tamże, I, kan. 52, POr 8, 635 (tłum. własne).

71 Por. tamże.

72 Tamże, I, kan. 52, POr 8, 635-636 (tłum. własne).

73 Tamże, I, kan. 52, POr 8, 637 (tłum. własne); por. K. K 1 a u z a, Diakon w Kościele syryjskim (III-IV w.), Vox Patrum 9(1989)17, s. 679.

74 Por. C e zary z A rl es, Sermo I, 15, CCL 103, 175.

75 Te n ż e, Vita Caesarii I, 56, Patrologiae cursus completus. Series Latina I-CCXVII (dalej: PL) 67, 1038 (tłum. własne); por. A. Ż u r e k, Formacja intelektualno-ascetyczna duchowieństwa w I-II wieku w Galii na podstawie Pism św. Cezarego z Arles, Vox Patrum 13-15 (1993-1995) 24-29, s. 177-178. 
Eucharystii zalicza on: czytanie Ewangelii; podawanie wiernym in tencji modlitwy powszechnej; usługiwanie kapłanowi; rozdzielanie wiernym Komunii św.; ewentualne podawanie wiernym wskazówek dotyczących gestów i postaw ciała; w przypadku nieobecności innych usługujących, w zależności od potrzeby, spełnianie funkcji do nich należących. ${ }^{76}$

W rozdziale IV wspomnianego Ogólnego wprowadzenia (numery 128-141) omawia się w sposób szczegółowy czynności diakońskie w odniesieniu do poszczególnych części mszy św.

\section{Obrzędy wstępne}

Obrzędy wstępne ${ }^{77}$ mają przygotować wiernych do uważnego słuchania słowa Bożego i godnego celebrowania Eucharystii. Diakon posługujący Ludowi Bożemu pomaga mu wejść w klimat celebracji przez świadome, czynne i owocne uczestnictwo. Do diakona należy też, by we współpracy z innymi posługującymi przygotować wcześniej to wszystko, co jest niezbędne do celebracji.

Posługą właściwą diakona, przynajmniej podczas niedzielnej mszy św., jest obrzęd przy ję c i a, szczególnie zalecany przez księgi liturgiczne. Przyjęcie stanowi gest ukazujący w dynamice zebrania ludzi braterstwo i jedność Chrystusową. W ten sposób podkreśla, że spotkanie nie ma charakteru anonimowości, ale rodzinności, w którym wzajemne poznanie i świadomość wezwania po imieniu jest koniecznym wymogiem dla ochrzczonych. Posługa diakona czyni więc zgromadzenie gościnnym dla wszystkich.

76 Por. OWMR, nr 127-138.

77 Tamże, nr 128: „W procesji do ołtarza diakon, ubrany w szaty liturgiczne, poprzedza kapłana wówczas, gdy niesie księgę Ewangelii, w przeciwnym razie idzie obok niego”; nr 129: „Razem z kapłanem diakon składa ołtarzowi należną cześć, a następnie razem z nim podchodzi do ołtarza. Jeśli niósł księgę Ewangelii, kładzie ją na ołtarzu, razem z kapłanem całuje ołtarz na znak czci, po czym, jeśli stosuje się okadzenie, asystuje kapłanowi podczas nałożenia kadzidła i okadzania ołtarza”; nr 130: „Po okadzeniu ołtarza udaje się z kapłanem do siedzeń i tam pozostaje obok kapłana, usługując mu w miarę potrzeby". 
Księgi liturgiczne sugerują, by troszczyć się o te celebracje, które umożliwiają wszystkim wiernym czuć się jak we własnym domu Jedynego Pana. Staje się to możliwe dzięki sposobowi, w jaki zostają oni przyjęci, a także dzięki solidarności i wspólnocie w jedynej Ofierze Chrystusa. ${ }^{78}$

Przez a k t p o k u t n y członkowie zgromadzenia uświadamiają sobie, że stanowią lud grzeszników, który dostępuje zbawienia. Wezwania mają pomóc wiernym w przyjęciu postawy gotowości do odnowy swego życia.

Kapłan wzywa wiernych do aktu pokuty, diakon zaś śpiewa lub recytuje niektóre wezwania, na które lud odpowiada. Po zakończeniu wezwań kapłan prosi Boga o odpuszczenie grzechów. ${ }^{79}$

\section{Liturgia Stowa}

W Ogólnym wprowadzeniu do Mszału rzymskiego czytamy: „Podczas Alleluja lub innego śpiewu diakon usługuje kapłanowi przy nałożeniu kadzidła, gdy są okadzenia. Następnie pochyla się przed kapłanem i prosi go o błogosławieństwo mówiąc półgłosem: «Pobłogosław mnie, ojcze». Kapłan udziela mu błogosławieństwa: «Niech Pan będzie w sercu twoim» itd., diakon odpowiada: «Amen», po czym bierze księgę Ewangelii z ołtarza, jeśli jest tam złożona, i udaje się na ambonę; na ambonie, diakon pozdrawia wiernych, okadza księgę i czyta Ewangelię. Na zakończenie całuje księgę na znak czci, mówiąc przy tym cicho: «Niech słowa Ewangelii» itd., i powraca do kapłana. Jeśli nie ma homilii ani wyznania wiary, może pozostać na ambonie podczas modlitwy powszechnej, jednak bez ministrantów, którzy odchodzą" ${ }^{80}$

78 Por. E. P e trol in o, Diakoni, zwiastuni Słowa Bożego, szafarze ołtarza i miłosierdzia, s. 52; G. O rl a n d i, I ministeri del diacono nella celebrazione eucaristica, Il diaconato in Italia 88/1992, s. 42-43.

79 Por. E. P e troli n o, Diakoni, zwiastuni Słowa Bożego, szafarze ołtarza i miłosierdzia, s. 53.

${ }^{80}$ OWMR, nr 131; por. G. O r 1 a n d i, I ministeri del diacono nella celebrazione eucaristica, s. 43-44; D. M e s s i n a, I segni del celebrare e la simbolica 
Diakon, po wstępie do modlitwy wiernych uczynionym przez kapłana, podaje poszczególne jej wezwania. Dokonuje tego z ambony lub innego odpowiedniego miejsca. ${ }^{81}$

Ponadto diakonowi w czasie sprawowania liturgii Wigilii Paschalnej powierza się tradycyjnie śpiew Orędzia Paschalnego. Najstarsze świadectwa ukazują tę modlitwę, głoszącą Chrystusa zmartwychwstałego, jako laus cerei lub benedictio cerei, która towarzyszy procesji z paschalną pochodnią. ${ }^{82}$ Istnienie tekstu tej modlitwy potwierdza świadectwo św. Augustyna. ${ }^{83}$

Exultet rozpoczyna hymn paschalnej radości, ogłaszany przez diakona aniołom, którzy byli pierwszymi świadkami zmartwychwstania Jezusa Chrystusa. Tę paschalną radość diakon ogłasza następnie ziemi, wyzwolonej z ciemności grzechu, oraz Matce-Kościołowi, reprezentowanemu przez wiernych obecnych w świątyni. Powyższe odniesienie umożliwia diakonowi zwrócenie się do obecnych z prośbą o wspólną modlitwę, aby w ten sposób chwała świecy paschalnej była

diaconale, w: M. R u s s o t to (red.), Dal tempo alla strada... la martyria della profezia. Corsi di formazione permanente per Presbiteri e Diaconi, t. IV, Palermo 2002-2003, s. 164; R. S e l e j d a k, Diakonat stały w świetle dokumentów Soboru Watykańskiego II, posoborowego Urzędu Nauczycielskiego Kościoła i narodowych „Rationes institutionis diaconorum permenentium”, s. 308.

${ }^{81}$ Por. OWMR, nr 132; G. O r 1 a n d i, I ministeri del diacono nella celebrazione eucaristica, s. 44; G. P. C i g a r i n i, La formazione dei diaconi permanenti per una prassi ecclesiale di rinnovamento, Il diaconato in Italia 110/1998, s. 41-42; G. B a r r a c a n e, L'azione d'intermediazione del diacono, tamże, s. 54; R. S e l e j d a k, Diakonat stały w świetle dokumentów Soboru Watykańskiego II, posoborowego Urzędu Nauczycielskiego Kościoła i narodowych „Rationes institutionis diaconorum permenentium”, s. 308.

82 Por. C. G i r a u d o, Le ascendenze biblico-giudaiche dell'Exultet, Rassegna di Teologia 25/1984, s. 113-131, 227-243; R. S e 1 e j d a k, Diakonat stały w świetle dokumentów Soboru Watykańskiego II, posoborowego Urzędu Nauczycielskiego Kościoła i narodowych „Rationes institutionis diaconorum permenentium”, s. 309.

83 Por. Augu st y n, De Civitate Dei XV, 22, CCL 48, 487. 
pełna i doskonała. Śpiew zaś samego Orędzia Paschalnego stanowi najbardziej wzniosłe zadanie liturgiczne całej posługi diakona. ${ }^{84}$

\section{Liturgia eucharystyczna}

Obrzędy liturgii eucharystycznej urzeczywistniają i rozwijają gesty, które Jezus uczynił w czasie Ostatniej Wieczerzy, a więc wzięcie chleba, składanie dziękczynienia, połamanie chleba i podanie kielicha. Gesty te uobecniają się w Eucharystii, w obrzędzie przygotowania darów, w Modlitwie eucharystycznej, w łamaniu chleba i w obrzędzie Komunii św. ${ }^{85}$

I. Obrzę d p r zyg ot ow a n i a d a rów. Ogólne wprowadzenie do Mszału rzymskiego stwierdza, że diakon przed przygotowaniem darów, przy pomocy innych usługujących, przygotowuje ołtarz. Do niego należy też przygotowanie naczyń eucharystycznych. Diakon towarzyszy kapłanowi podczas przyjmowania darów od ludu. Potem podaje mu patenę z chlebem przeznaczonym do konsekracji; wlewa do kielicha wino i trochę wody, mówiąc cicho: „Przez to misterium” itd., po czym kielich podaje kapłanowi. Przygotowanie kielicha, tj. wlania wina i wody, może dokonać również przy kredensie. W przypadku, gdy są okadzenia, diakon usługuje kapłanowi okadzającemu dary ofiarne i ołtarz, a później sam, lub inny usługujący, okadza kapłana i lud. ${ }^{86}$

${ }^{84}$ Por. C. G i r a u d o, Le ascendenze biblico-giudaiche dell'Exultet, s. 230; por. E. P e t r o 1 i n o, Diakoni, zwiastuni Słowa Bożego, szafarze ołtarza i miłosierdzia, s. 55; R. S e l e j d a k, Tożsamość, duchowość, formacja i postuga diakonów statych, s. 117; t e n ż e, Diakonat stały w świetle dokumentów Soboru Watykańskiego II, posoborowego Urzędu Nauczycielskiego Kościoła i narodowych „Rationes institutionis diaconorum permenentium”, s. 309.

${ }^{85}$ Por. E. P e trol i n o, Diakoni, zwiastuni Słowa Bożego, szafarze oltarza i miłosierdzia, s. 55; R. S e l e j d a k, Tożsamość, duchowość, formacja i posługa diakonów stałych, s. 117; t e n ż e, Diakonat stały w świetle dokumentów Soboru Watykańskiego II, posoborowego Urzędu Nauczycielskiego Kościoła i narodowych „,Rationes institutionis diaconorum permenentium”, s. 309.

${ }^{86}$ Por. OWMR, nr 133; por. G. O rl a n d i, I ministeri del diacono nella celebrazione eucaristica, s. 44; D. M e s s i n a, I segni del celebrare e la simbolica 
II. Modlitwa e ucharystyczna. Modlitwa eucharystyczna, będąca w centrum liturgii eucharystycznej, nadaje jej sens i znaczenie. W pierwszych wiekach historii Kościoła zadaniem diakona było przywołanie wiernych do skupienia przez krótkie pouczenie poprzedzające modlitwę eucharystyczną. W czasach współczesnych takie przywołanie, wyrażane przez diakona, ma miejsce w liturgii św. Jana Chryzostoma, w obrządku bizantyjskim. ${ }^{87}$

Według Ogólnego wprowadzenia do Mszału rzymskiego, ,[w] czasie Modlitwy eucharystycznej diakon stoi w pobliżu kapłana, nieco za nim i kiedy trzeba usługuje mu przy kielichu i mszale". ${ }^{88}$ Następnie „[w] czasie doksologii kończącej Modlitwę eucharystyczną, stojąc obok kapłana, który podnosi patenę z hostią, diakon trzyma podniesiony kielich aż do wypowiedzenia przez lud aklamacji «Amen»". ${ }^{89}$

Diakon nie może wypowiadać słów Modlitwy eucharystycznej, ani wykonywać czynności i gestów właściwych temu, który przewodniczy i konsekruje. ${ }^{90}$

diaconale, s. 174-175; R. S e l e j d a k, Diakonat stały w świetle dokumentów Soboru Watykańskiego II, posoborowego Urzędu Nauczycielskiego Kościoła i narodowych „Rationes institutionis diaconorum permenentium”, s. 309.

87 Por. E. P e trol i n o, Diakoni, zwiastuni Słowa Bożego, szafarze ołtarza i miłosierdzia, s. 56; R. S e l e j d a k, Tożsamość, duchowość, formacja i posługa diakonów stałych, s. 118; t e n ż e, Diakonat stały w świetle dokumentów Soboru Watykańskiego II, posoborowego Urzędu Nauczycielskiego Kościoła i narodowych „,Rationes institutionis diaconorum permenentium”, s. 309.

88 OWMR, nr 134.

89 Tamże, nr 135.

90 Por. KPK, kan. 907; Kongregacja ds. Duchowieństwa, Papieska Rada ds. Świeckich, Kongregacja Nauki Wiary, Kongregacja ds. Kultu Bożego i Dyscypliny Sakramentów, Kongregacjads. Biskupów, Kongregacja ds. Ewangelizacji Narodów, Kongregacja ds. Instytutów Życia Konsekrowanego i Stowarzyszeń Życia Apostolskiego, Papieska Rada $\mathrm{d}$ s. Inter p r e t a c j i Te k s tów P r a w y c h, Istruzione su alcune questioni circa la collaborazione dei fedeli laici al ministero dei sacerdoti „Ecclesiae de mysterio", 15 VIII 1997, art. 6, EV 16/1997, s. 589. 
III. Z n a k p o k o j u. W czasie tego obrzędu zgromadzenie wiernych prosi o pokój i jedność dla Kościoła oraz dla całej ludzkości. Diakon, stosownie do okoliczności, gdy kapłan odmówi modlitwę o pokój, a lud na jego słowa: «Pokój Pański niech zawsze będzie z wami», odpowie: «I z duchem twoim», wzywa wiernych do przekazania sobie znaku pokoju słowami: «Przekażcie sobie znak pokoju». Przyjmuje następnie od kapłana znak pokoju i może go przekazać innym członkom asysty, stojącym w pobliżu. $^{91}$

\section{Komunia święta}

Diakon jest zwyczajnym szafarzem Komunii św. ${ }^{92}$ Autorem, który po raz pierwszy w historii Kościoła ukazuje diakona rozdzielającego Komunię św. wiernym był Justyn. W Apologii pierwszej, pisze: „W dniu zaś zwanym dniem Słońca odbywa się w oznaczonym miejscu zebranie wszystkich nas, zarówno z miast, jak i ze wsi. Czyta się wtedy pamiętniki apostolskie lub pisma prorockie, jak długo na to czas pozwala, gdy zaś lektor skończy, przełożony żywym słowem upomina i zachęca do naśladowania tych wzniosłych nauk. Następnie powstajemy z miejsc i modlimy się, po modlitwie zaś następują opisane już poprzednio ceremonie, mianowicie przynosi się chleb oraz wino z wodą, nad którymi przełożony odprawia modły i dziękczynienia, ile tylko może, lud zaś odpowiada mu radosnym «amen»-wreszcie następuje rozdawanie każdemu cząstki pokarmu eucharystycznego; nieobecnym zanoszą go diakoni. Kogo stać na to, a ma dobrą wolę, ofiaruje datki, jakie chce i może, po czym całą

${ }^{91}$ Por. OWMR, nr 136; por. G. O $\mathrm{r}$ l a n d i, I ministeri del diacono nella celebrazione eucaristica, s. 44-45; R. S e l e j d a k, Diakonat stały w świetle dokumentów Soboru Watykańskiego II, posoborowego Urzędu Nauczycielskiego Kościoła i narodowych ,,Rationes institutionis diaconorum permenentium”, s. 310.

92 Por. KPK, kan. 910 § 1; por. G. P. C i g a r i n i, Servire l'eucaristia, Il diaconato in Italia 91-92/1993, s. 124; T. R i n c ó n - P é r e z, El orden de los clérigos o ministros sagrados, Pamplona 2009, s. 347; R. S e l e j d a k, Diakonat stały w świetle dokumentów Soboru Watykańskiego II, posoborowego Urzędu Nauczycielskiego Kościoła i narodowych , Rationes institutionis diaconorum permenentium”, s. 310. 
zbiórkę składa się na ręce przełożonego. Ten roztacza opiekę nad sierotami, wdowami, chorymi, lub też z innego powodu cierpiącymi niedostatek, a także nad więźniami oraz obcymi goszczącymi w gminie; jednym słowem spieszy z pomocą wszystkim potrzebującym". 93

Według Justyna, biskup, nazywany przełożonym, jest tym, który stoi na czele wspólnoty i przewodniczy celebracji Eucharystii. To on wygłasza homilię po lekturze tekstów biblijnych ze Starego i Nowego Testamentu. Ponadto odmawia modlitwę eucharystyczną oraz rozdaje obecnym Komunię św. Do zadań diakona zaś należy iść z Komunią św. do tych, którzy byli nieobecni na Eucharystii. ${ }^{94}$

Hipolit, opisując celebrację Eucharystii w Tradycji Apostolskiej, wspomina że diakon przynosi biskupowi dary ofiarne i gdy nie ma dostatecznej liczby prezbiterów, trzyma kielich w czasie Komunii i powoli, w odpowiedniej kolejności, podaje do skosztowania Krew Pańską: „Teraz diakoni podadzą biskupowi dary ofiarne, nad którymi odmówi modlitwy dziękczynne (...). Równocześnie zaś prezbiterzy lub - gdy ich nie ma w dostatecznej ilości - diakoni niech trzymają kielichy i powoli, w odpowiedniej kolejności niech podają do skosztowania: najpierw kielich z wodą, później z mlekiem, w końcu z winem, trzykrotnie przy każdym z nich mówiąc: «W Bogu, Ojcu wszechmogącym» - na co przyjmujący odpowie: «Amen»; «I w Panu Jezusie Chrystusie, i w Duchu Świętym, i w świętym Kościele» a przyjmujący znów powie: «Amen»". ${ }^{5}$

Diakon razem z prezbiterami łamie też chleb eucharystyczny: „W niedzielę biskup będzie, w miarę możliwości osobiście, rozdawał całemu ludowi chleb, przy czym łamać go będą diakoni. Także prezbiterzy będą rozdawali chleb łamany: diakon podejdzie do prezbitera i posunie mu kosz, on zaś będzie brał i wręczał ludziom. O rozdawaniu chleba w inne dni zadecyduje biskup". ${ }^{96}$

93 J u s t y n, Apologia I pro Christianis, 67, Patrologiae cursus compeltus. Series Graeca I-CLXI (dalej: PG) 6, 430 (tłum. własne).

94 Por. S. Z a r d o n i, I diaconi nella Chiesa, s. 27-29.

$95 \mathrm{H}$ i p ol i t, La Tradition Apostolique, SCh 11 bis, 90-94 (tłum. własne).

96 Tamie, 96 (tłum. własne). 
$\mathrm{Z}$ biegiem czasu pojawiły się w tym względzie pewne nadużycia. Sobór w Nicei (325 r.) w kanonie 18 mówi: „Dotarła wiadomość do świętego i wielkiego soboru, że w niektórych miejscowościach i miastach diakoni udzielają Komunii prezbiterom; nie jest dozwolone przez żaden kanon ani zwyczaj, iż aby ci, którzy ofiarują ciało Chrystusa, otrzymywali je od tych, którzy nie mają władzy ofiarowania go. Tak samo jak wiemy, że niektórzy diakoni w obecności biskupa sami biorą sobie Eucharystię. W związku z tym chcemy, aby diakoni pozostawali na swoim miejscu, w przekonaniu, iż są w służbie biskupowi i niżej postawieni od prezbiterów. To jest racja, aby diakoni przystępowali do Komunii po prezbiterach, przyjmując ją od biskupa lub prezbitera. Ponadto nie wolno diakonowi zajmować miejsca pomiędzy prezbiterami: jeśli do tego dochodzi, to jest to wbrew kanonom i sprawiedliwemu porządkowi. Ten, który nie będzie chciał się dostosować do tych reguł, musi pozostawić diakonię". ${ }^{97}$

Bardzo ważnym świadectwem potwierdzającym, że najważniejszym zadaniem diakonów podczas Eucharystii jest udzielanie razem z biskupem Komunii św. są Konstytucje Apostolskie. Opisują one Komunię św. na zakończenie mszy celebrowanej przez biskupa w następujący sposób: „Biskup niechaj zwróci się do ludu ze słowami: «Święte dla świętych». Lud zaś niech odpowie: «Jeden Święty, jeden Pan, Jezus Chrystus, w chwale Boga Ojca, błogosławiony jesteś na wieki. Amen. Chwała na wysokości Bogu, a na ziemi pokój, a wśród ludzi dobra wola. Hosanna Synowi Dawidowemu, błogosławiony, który idzie w imię Pańskie. Pan Bóg ukazał się w nas. Hosanna na wysokościach». Następnie niech biskup przyjmie Komunię, potem prezbiterzy, diakoni, subdiakoni, lektorzy, kantorzy, asceci, a spośród kobiet - diakonise, dziewice i wdowy, po nich młodzież i wreszcie cały lud po kolei, z szacunkiem i czcią, w skupieniu. Biskup niechaj udziela Chleba ofiarnego mówiąc: "Ciało Chrystusa», a ten, który Go przyjmuje, odpowie: «Amen». Diakon zaś niech trzyma kielich, a podając, mówi: «Krew Chrystusa, kielich życia»; a mający pić niech odpowie: «Amen». Podczas przyjmowania Komunii przez wszystkich

97 Kan. 18, Mansi II, 904 (tłum. własne). 
pozostałych, należy śpiewać Psalm 33. Gdy już wszyscy mężczyźni i kobiety przyjmą Komunię, diakoni mają zebrać to, co pozostało i odnieść do pastoforium". ${ }^{98}$

Diakon zatem jest szafarzem Krwi Pańskiej i pełni tę posługę u boku biskupa w obecności prezbiterów.

Rozdawanie Komunii św. wiernym przez diakonów wzmiankuje także fragment Konstytycji opisującej poszczególne posługi kościelne: „Biskup błogosławi (...), nakłada ręce, wyświęca, celebruje Eucharystię; otrzymuje błogosławieństwo od biskupów, nigdy od prezbiterów; biskup może odwołać z urzędu każdego duchownego, który na to zasługuje, z wyjątkiem biskupa: sam tego nie może uczynić. Prezbiter błogosławi (...); otrzymuje błogosławieństwo od biskupa i od innego prezbitera (...); nakłada ręce, nie wyświęca; nie usuwa z urzędu, może jednak ekskomunikować niższego sobie urzędem, jeśli zasługuje na taką karę. Diakon nie błogosławi (...), otrzymuje błogosławieństwo od biskupa i prezbitera; (...) nie składa ofiary; jednakże jest tym, który udziela Komunii świętej po złożeniu ofiary przez biskupa i prezbitera. Czyni to nie jako kapłan, ale raczej jako posługujący kapłanom. Żaden z pozostałych duchownych nie może robić tego, co robi diakon". 99

Ponadto diakona jako szafarza Komunii św. pod dwiema postaciami ukazują Kanony Apostolskie. ${ }^{100}$ Ogólne wprowadzenie do Mszału rzymskiego opisuje powyższe zadanie diakona w następujący sposób: „Po Komunii kapłana diakon przyjmuje Komunię pod obiema postaciami, a następnie pomaga kapłanowi w rozdzielaniu Komunii ludowi. Gdyby Komunii udzielano pod obiema postaciami, diakon usługuje przy kielichu, z którego pije jako ostatni”. ${ }^{101}$ „Kiedy

98 Constitutiones Apostolorum, VIII, 13, 13-17, DCA I, 517-519 (tłum. własne).

99 Tamże, VIII, 28, 2-8, DCA I, 531 (tłum. własne).

${ }^{100}$ Por. Les 127 Canons des Apôtres, I, kan. 21, POr 8, 591.

${ }^{101}$ OWMR, nr 137; G. O rl a n d i, I ministeri del diacono nella celebrazione eucaristica, s. 45; D. M e s s i n a, I segni del celebrare e la simbolica diaconale, s. 175-177; R. S e le j d a k, Diakonat stały w świetle dokumentów Soboru Watykańskiego II, posoborowego Urzędu Nauczycielskiego Kościoła i narodowych „Rationes institutionis diaconorum permenentium”, s. 313. 
skończy się rozdzielanie Komunii, diakon powraca z kapłanem do ołtarza. Jeśli pozostały okruszyny, zbiera je, a następnie odnosi kielich i inne naczynia liturgiczne na kredens. Po puryfikacji naczyń przykrywa je, jak zwykle; w tym czasie kapłan powraca do krzesła. Wolno jednak naczynia przeznaczone do puryfikacji pozostawić na kredensie, umieszczone na korporale i odpowiednio nakryte, a puryfikacji dokonać po Mszy, po odesłaniu ludu". ${ }^{102}$

W tym kontekście warto też zwrócić szczególniejszą uwagę na fakt, że diakon jest szafarzem Komunii św. z kielicha. ${ }^{103}$

O znaczeniu Komunii św. pod dwiema postaciami Ogólne wprowadzenie do Mszału rzymskiego mówi, że ,ze względu na wymowę znaku Komunia święta nabiera pełniejszego wyrazu, gdy jest przyjmowana pod obiema postaciami. W tej bowiem formie ukazuje się w doskonalszym świetle znak Uczty eucharystycznej i jaśniej wyraża się wola dopełnienia nowego i wiecznego przymierza we Krwi Pana; jaśniej też uwydatnia się związek istniejący pomiędzy Ucztą eucharystyczną a ucztą eschatologiczną w królestwie Ojca". ${ }^{104}$

Powyższe założenie wskazuje, że Komunia św. pod obiema postaciami stanowi ,skuteczny znak” objawiający i jednocześnie aktualizujący przekazanie w pełni obecności Pana i Jego zbawienia. ${ }^{105}$

Ogólne wprowadzenie do Mszału rzymskiego, oprócz potwierdzenia zasady, że ,przyjmuje się całego Chrystusa i prawdziwy Sakrament także pod jedną tylko postacią", ${ }^{106}$ podaje racje, dla

102 OWMR, nr 138.

${ }^{103}$ Por. tamże, nr 244-252; P. C i g a r i n i, La formazione dei diaconi permanenti per una prassi ecclesiale di rinnovamento, s. 42-43; G. B a r r a c a n e, L'azione d'intermediazione del diacono, s. 54; R. S e l e j d a k, Diakonat stały w świetle dokumentów Soboru Watykańskiego II, posoborowego Urzędu Nauczycielskiego Kościoła i narodowych „Rationes institutionis diaconorum permenentium”, s. 313.

${ }^{104}$ OWMR, nr 240.

${ }_{105}$ Por. E. P e trol i n o, Diakoni, zwiastuni Słowa Bożego, szafarze ołtarza i miłosierdzia, s. 58; R. S e l e j d a k, Tożsamość, duchowość, formacja i postuga diakonów statych, s. 120; t e n ż e, Diakonat stały w świetle dokumentów Soboru Watykańskiego II, posoborowego Urzędu Nauczycielskiego Kościoła i narodowych „,Rationes institutionis diaconorum permenentium”, s. 314.

${ }^{106}$ OWMR, nr 241. 
których prawda znaku „nabiera pełniejszego wyrazu” w Komunii pod dwiema postaciami. ${ }^{107}$ Ponadto przewiduje ono cztery sposoby przyjmowania Komunii św. z kielicha: pijąc bezpośrednio z kielicha; ${ }^{108}$ przez zanurzenie; ${ }^{109}$ przy użyciu rurki;; ${ }^{110}$ przy użyciu łyżeczki. ${ }^{11}$

W praktyce duszpasterskiej najczęściej stosuje się dwa pierwsze sposoby. Dwie ostatnie praktyki stosuje się jedynie w wyjątkowych sytuacjach.

Posługa udzielania przez diakona Komunii św. pod postacią wina jest jego „właściwą posługą”, wynikającą z tradycji, która swoimi początkami sięga trzeciego stulecia.

Święty Tomasz z Akwinu, interpretując teologicznie tę posługę diakona, pisze: „Krew oznacza odkupienie, które płynie od Chrystusa do ludu, tak że Krew jest zmieszana z wodą dla wskazania na lud. Teraz, ponieważ diakoni są między kapłanem a ludem, diakonom zleca się bardziej rozdzielanie Krwi niż rozdzielanie Ciała". ${ }^{12}$ Tak więc, według św. Tomasza, diakon, udzielając Eucharystii pod postacią wina, jawi się jako pośrednik między przewodniczącym celebracji a wiernymi, ukazując $w$ ten sposób potrzeby i pragnienia wspólnoty chrześcijańskiej.

Zdaniem G. Agagliati, udzielanie Komunii św. wiernym przez diakona ma podwójne znaczenie. $Z$ jednej strony posługa ta ukazuje, że diakon jest szafarzem zwyczajnym Ciała i Krwi Pańskiej w odróżnieniu od szafarzy nadzwyczajnych, którymi mogą być osoby świeckie lub konsekrowane. $Z$ drugiej strony, posługa ta ma znaczenie szczególne, gdyż jest „posługą pośrednictwa”. Przypomina ona, że

\footnotetext{
${ }^{107}$ Por. tamże, nr 242.

${ }_{108}$ Por. tamże, nr 244-245.

${ }_{109}$ Por. tamże, nr 246-247.

110 Por. tami̇e, nr 248-250.

111 Por. tami̇e, nr 251-252.

112 Tomas z z A kw in u, Summa Theologiae, BACr, t. 4, cz. III, Madrid 1958, 92 , 3, 1: „Quia sanguis designat redemptionem a Christo in populum derivatam; unde et Sanguini admiscetut aqua, quae significat populum. Et quia diakoni sunt inter sacerdotem et populum, magis convenit diaconibus dispensatio sangunis quam dispensatio corporis".
} 
osoby, które dzielą z diakonem życie codzienne, w wśród nich przede wszystkim członkowie rodziny, stają przed nim, aby otrzymać Ciało Chrystusa, które ich w tym życiu umacnia. ${ }^{113}$

\section{Obrzędy zakończenia}

Posługi diakona związane z obrzędami zakończenia mszy św. są opisane w Ogólnym wprowadzeniu do Mszału rzymskiego w numerach 139-141. Stwierdza się tam, że:

- „Gdy zostanie odmówiona modlitwa po Komunii, diakon podaje ludowi krótkie ogłoszenia, jeśli są przewidziane, chyba że sam kapłan wolałby to uczynić;; 114

- „Gdy kapłan udzieli błogosławieństwa, diakon odsyła lud mówiąc: «Idźcie w pokoju Chrystusa»”; 115

- „Następnie razem z kapłanem całuje ołtarz na znak czci i po oddaniu należnego ukłonu odchodzi w podobny sposób, w jaki przyszedł na początku". ${ }^{116}$

Zdaniem A. Borrasa, posługa liturgiczna diakonów w czasie mszy św. ma przypominać wspólnocie wiernych, że nie ma Eucharystii bez umywania nóg. ${ }^{117}$

Komunia święta poza mszą św. i kult Eucharystii

II Sobór Watykański ukazuje Eucharystię jako „źródło i szczyt całej ewangelizacji”. ${ }^{118} \mathrm{~W}$ niej bowiem zawiera się „,całe dobro duchowe Kościoła, to znaczy sam Chrystus, nasza Pascha i Chleb żywy, który przez swoje ożywione przez Ducha Świętego i ożywiające Ciało daje życie ludziom i w ten sposób usilnie ich zaprasza i pobudza, żeby

113 Por. G. A g a g 1 i a t i, Ministero della soglia e del ponte nella celebrazione eucaristica, Il diaconato In Italia 133/2005, s. 13.

114 OWMR, nr 139.

115 Tamże, nr 140.

116 Tamże, nr 141.

${ }^{117}$ Por. A. B o r r a s, Il diaconato, vittima della sua novità, s. 334.

118 DP, nr 5. 
samych siebie, swoją pracę i wszystkie rzeczy stworzone wraz z Nim składali w ofierze". 119

Celebracja Eucharystii stanowi centrum całego życia chrześcijańskiego. Dlatego Komunia św. poza mszą św. może być udzielana jedynie z ważnych powodów. Przypadek ten jest wskazany we Wprowadzeniu do księgi liturgicznej Komunia święta i kult tajemnicy eucharystycznej poza Msza święta jako drugorzędny cel przechowywania Eucharystii, ponieważ pierwszym i zasadniczym celem jest udzielanie Wiatyku. ${ }^{120}$

Udzielanie Komunii św. poza mszą św. może być powierzone diakonowi jako szafarzowi zwyczajnemu Komunii św. ${ }^{121}$ Posługę tę powinien on sprawować według obrzędu celebracji wspólnotowej ${ }^{122}$ albo według obrzędu krótszego. ${ }^{123}$

W przypadku zaś Komunii św. i Wiatyku zanoszonych chorym i umierającym, rytuał przewiduje, aby diakon udzielał Komunii chorym zgodnie z obrzędem zawartym w księdze liturgicznej Sakramenty chorych. Obrzędy $i$ duszpasterstwo, która zawiera ryt zwykły ${ }^{124}$ i krótszy. ${ }^{125}$

Jeśli chodzi o Wiatyk, to jest on zanoszony umierającym również przez diakona. ${ }^{126}$ Ta posługa diakona wynika z jasnego wyjaśnienia

119 Tamże.

${ }^{120}$ Por. Komunia święta i kult tajemnicy eucharystycznej poza Msza święta, Katowice 1985, nr 5.

${ }^{121}$ Por. tamże, nr 17; por. T. R i n c ó n - P é r e z, El orden de los clérigos o ministros sagrados, s. 347; R. S e l e j d a k, Diakonat stały w świetle dokumentów Soboru Watykańskiego II, posoborowego Urzędu Nauczycielskiego Kościoła i narodowych „Rationes institutionis diaconorum permenentium”, s. 316.

122 Por. Komunia święta i kult tajemnicy eucharystycznej poza Msza świętą, nr 26-41.

${ }^{123}$ Por. tamże, nr 42-54.

124 Por. Sakramenty chorych. Obrzędy i duszpasterstwo, Katowice 2001, nr 52-66.

${ }^{125}$ Por. tamże, nr 67-71.

126 Por. KPK, kan. 911 § 2; por. T. R i n c ó n - P é r e z, El orden de los clérigos o ministros sagrados, s. 347; R. S e l e j d a k, Diakonat staty w świetle dokumentów Soboru Watykańskiego II, posoborowego Urzędu Nauczycielskiego Kościoła i narodowych ,Rationes institutionis diaconorum permenentium, s. 316. 
zawartego w nr 52 wspomnianej księgi i jest sprawowana przez niego według ściśle określonego obrzędu liturgicznego. ${ }^{127}$

Ponadto diakon jest zwyczajnym szafarzem wystawienia Najświętszego Sakramentu i błogosławieństwa eucharystycznego. ${ }^{128}$ Jemu też przypada ewentualna niedzielna celebracja tego nabożeństwa w przypadku nieobecności prezbitera. ${ }^{129}$

\section{Sakrament małżeństwa}

Kodeks Prawa Kanonicznego postanawia, że diakon może asystować w imieniu Kościoła małżeństwu i błogosławić małżonków. ${ }^{130}$

Diakon może przewodniczyć celebracji sakramentu małżeństwa, kiedy ze słusznej przyczyny albo szczególnej sytuacji opuszcza się celebrowanie mszy św. W tym przypadku diakon musi otrzymać delegację od proboszcza lub miejscowego ordynariusza. ${ }^{131}$

${ }^{127}$ Por. Sakramenty chorych. Obrzędy i duszpasterstwo, nr 124-141.

${ }_{128}$ Por. KPK, kan. 943; por. P a w e 1 VI, Motu proprio „, Sacrum diaconatus ordinem", V, 22, 3, s. 702; T. R i n c ó n - P é r e z, El orden de los clérigos o ministros sagrados, s. 347; R. S e l e j d a k, Diakonat stały w świetle dokumentów Soboru Watykańskiego II, posoborowego Urzędu Nauczycielskiego Kościoła i narodowych „,Rationes institutionis diaconorum permenentium”, s. 316.

${ }^{129}$ Por. Kongregacja ds. Kultu Bożego i Dyscypliny Sak r a m e n tó w, Direttorio per le celebrazioni domenicali in assenza del presbitero „Christi Ecclesia”, 2 VI 1988, nr 38, EV/1988-1989, s. 463; K o n g re g a c j a d s. Duchowieństwa, Papieska Rada ds. Świeckich, Kongregacja Nauki Wiary, Kongregacja ds. Kultu Bożego i Dyscypliny Sakramentów, Kongregacja ds. Biskupów, Kongregacja ds. Ewangelizacji Narodów, Kongregacja ds. Instytutów Życia Konsekrowanego i Stowarzyszeń Życia Apostolskiego, Papieska Rada ds. Interpretacji Tekstów Prawny ch, Istruzionesu alcune questioni circa la collaborazione dei fedeli laici al ministero dei sacerdoti „Ecclesiae de mysterio”, art. 7, s. 591; DPŻDS, nr 32.

${ }^{130}$ Por. KPK, kan. 1108 § 1; por. T. R i n c ó n - P é r e z, El orden de los clérigos o ministros sagrados, s. 348; R. S e 1 e j d a k, Diakonat staty w świetle dokumentów Soboru Watykańskiego II, posoborowego Urzędu Nauczycielskiego Kościoła $i$ narodowych ,Rationes institutionis diaconorum permenentium”, s. 317.

${ }^{131}$ Por. KK, nr 29; KPK, kan. 1108 § 1-2; DPŻDS, nr 33. 
Delegacja ta może być udzielona do ogółu przypadków ${ }^{132}$ lub w formie subdelegacji. ${ }^{133}$

W niebezpieczeństwie śmierci oraz w sytuacji wykrycia przeszkody, gdy wszystko jest już przygotowane do zawarcia małżeństwa i nie da się odłożyć ceremonii bez prawdopodobnego niebezpieczeństwa wielkiego zła, diakon asystujący przy zawieraniu związku małżeńskiego ma władzę dyspensowania od przeszkód małżeńskich zgodnie z przepisami prawa. ${ }^{134}$

Diakonom może być powierzona troska o duszpasterstwo rodzin, za które zasadniczo ponosi odpowiedzialność biskup. Ich zadaniem będzie niesienie pomocy rodzinom w rozwiązywaniu problemów o charakterze moralnym, liturgicznym, osobistym i społecznym. ${ }^{135}$ Taka pomoc może być udzielana na poziomie diecezjalnym lub lokalnym pod kierownictwem proboszcza, wykorzystując do tego celu katechezy na temat małżeństwa, spotkania przygotowawcze przyszłych małżonków, celebracje sakramentu małżeństwa. Do diakonów może również należeć wspomaganie małżonków po ślubie, ażeby wiernie zachowując i chroniąc przymierze małżeńskie, osiągali w rodzinie życie coraz bardziej święte i doskonałe. ${ }^{136}$

Diakoni żonaci mogą być niezwykle pomocni w przybliżaniu tematyki związanej z miłością małżeńską, wartości ją chroniących, a także w tym wszystkim, co dotyczy ojcostwa chrześcijańskiego i ludzkiej odpowiedzialności. ${ }^{137}$

132 Por. KPK, kan. $1111 \S 1-2$.

${ }^{133}$ Por. tamże, kan. 137 § 3-4.

134 Por. tamże, kan. 1079; 1080; $1116 \S 2$.

135 Por. J a n P a w e $\nmid$ II, Adhortacja apostolska „Familiaris consortio”, 22 XI 1981, w: Adhortacje apostolskie Jana Pawła II, Kraków 1996, nr 73; por. G. B e 11 i a, I diaconi italiani e la loro Chiesa, w: t e $\mathrm{n} \dot{\mathrm{z}} \mathrm{e}$ (red.), La Chiesa diaconia universale di salvezza, Reggio Emilia 2004, s. 16-18; T. R i n c ó n - P é r e z, El orden de los clérigos o ministros sagrados, s. 348; R. S e le j d a k, Diakonat stały w świetle dokumentów Soboru Watykańskiego II, posoborowego Urzędu Nauczycielskiego Kościoła i narodowych „Rationes institutionis diaconorum permenentium”, s. 317.

${ }^{136}$ Por. KPK, kan. 1063.

${ }^{137}$ Por. J a n $\mathrm{P}$ awe $\nmid$ II, Discorso ai diaconi permanenti di Detroit, 19 IX 1987, nr 5, Insegnamenti 10/1987, s. 658-659; DPŻDS, nr 33; por. E. P e t r o 1 i n o, 
Opieka duszpasterska na chorymi

Zgodnie z Magisterium Kościoła, udzielanie sakramentu namaszczenia chorych jest zarezerwowane biskupowi oraz prezbiterom. Zasada ta wynika z faktu, że udzielanie sakramentu namaszczenia chorych jest ściśle związane z odpuszczeniem grzechów i godnym przyjęciem Eucharystii. ${ }^{138}$ Diakoni mogą jednak sprawować opiekę duszpasterską nad chorymi.

W Tradycji Apostolskiej Hipolit przypomina, że diakon i subdiakon informują biskupa wspólnoty o jej chorych członkach oczekujących na odwiedziny pasterza: „Każdy diakon i jego subdiakoni niech się starają być usłużni wobec biskupa; niech go powiadamiają o chorych, aby, jeśli zechce, mógł ich odwiedzić, wielką bowiem radość sprawia choremu, gdy widzi, że arcykapłan o nim pamięta". ${ }^{139}$

Opieka nad chorymi może przyjąć różne formy. Diakoni mogą udzielać duchowej pomocy chorym w znoszeniu cierpienia, przygotowywać ich do przyjęcia sakramentu namaszczenia, zastępować kapłana w przygotowaniu do śmierci, a także udzielać Wiatyku według przepisanego obrzędu. ${ }^{140}$

Diaconato e famiglia, w: M. R u s s o t t o (red.), Radici... il Mistero del Ministero. Corsi di formazione permanente per Presbiteri e Diaconi, t. I, Palermo 2001, s. 340-343; R. C a r $\mathrm{m}$ a g n a n i, Il diacono, leader di servizio, w: M. R u s s o t t o (red.), Discernimento... per ,,dire Dio” oggi. Corsi di formazione permanente per Presbiteri e Diaconi, t. II, Palermo 2001, s. 15-16; R. S e l e j d a k, Diakonat staty w świetle dokumentów Soboru Watykańskiego II, posoborowego Urzędu Nauczycielskiego Kościoła i narodowych ,, Rationes institutionis diaconorum permenentium”, s. 318.

${ }^{138}$ Por. DPŻDS, nr 34.

${ }^{139} \mathrm{H}$ i p o $\mathrm{l}$ i t, La Tradition Apostolique, 116 (tłum. własne).

${ }^{140}$ Por. DPŻDS, nr 34; por. P a w e 1 VI, Motu proprio „, Sacrum diaconatus ordinem", II, 10, s. 700; Kongrega cja ds. Duchowieńs twa, Papieska Rada ds. Świeckich, Kongregacja Nauki Wiary, Kongregacja ds. Kultu Bożego i Dyscypliny Sakramentów, Kongregacja ds. Biskupów, Kongregacja ds. Ewangelizacji Narodów, Kongregacja ds. Instytutów Życia Konsekrowanego i Stowarzyszeń Życia Apostolskiego, Papieska Rada ds. Inte r p reta c ji Tekstów P r aw n c h, Istruzione su alcune questioni circa 


\section{Liturgia Godzin}

Diakoni są zobowiązani przez Kościół do odprawiania Liturgii Godzin, w której całe Ciało Mistyczne łączy się w modlitwie kierowanej przez Chrystusa-Głowę do Ojca. Świadomi ciążącej na nich odpowiedzialności powinni oni codziennie celebrować Liturgię według zatwierdzonych ksiąg liturgicznych oraz w sposób określony przez Konferencję Biskupów. ${ }^{141}$

Diakoni, których zadaniem jest przewodniczenie celebracji wspólnotowej Liturgii Godzin, mogą nałożyć stułę albo dalmatykę, zwłaszcza w większe uroczystości. W czasie wspomnianej celebracji do nich należy rozpoczynanie przewodniczenia oficjum z psalmem wezwania, rozpoczynanie Modlitwy Pańskiej, odmówienie modlitwy na zakończenie, pozdrowienie ludu, udzielenie mu błogosławieństwa i rozesłanie. ${ }^{142}$

Ponadto diakoni winni troszczyć się o większy udział wspólnoty chrześcijańskiej w Liturgii Godzin, nie mającej nigdy charakteru prywatnego, ale zawsze będącej aktem własnym całego Kościoła, nawet wówczas, gdy sprawuje się ją indywidualnie. ${ }^{143}$

\section{Sakramentalia}

Diakoni są szafarzami sakramentaliów, czyli tych „znaków świętych, które na podobieństwo sakramentów wskazują przede wszystkim na duchowe dobra osiągane dzięki wstawiennictwu Kościoła.

la collaborazione dei fedeli laici al ministero dei sacerdoti „Ecclesiae de mysterio”, art. 9, s. 595-597.

${ }^{141}$ Por. KK, nr 30; KPK, kan. $276 \S 2,3^{\circ}$.

142 Por. E. P e trol i n o, Diakoni, zwiastuni Słowa Bożego, szafarze ołtarza i miłosierdzia, s. 62-63; R. S e le j d a k, Tożsamość, duchowość, formacja i posługa diakonów stałych, s. 125; t e n ż e, Diakonat stały w świetle dokumentów Soboru Watykańskiego II, posoborowego Urzędu Nauczycielskiego Kościoła i narodowych „,Rationes institutionis diaconorum permenentium”, s. 319.

${ }^{143}$ Por. DPŻDS, nr 35. 
Przygotowują one ludzi do przyjęcia właściwego skutku sakramentów i uświęcają różne okoliczności życia". ${ }^{144}$

We Wprowadzeniu do księgi Obrzędy błogosławieństw stwierdza się, że „diakonom przysługuje prawo przewodniczenia uroczystym błogosławieństwom”. ${ }^{145}$ Podobnie jak prezbitera, także diakona obowiązuje zasada, że w przypadku obecności szafarza lepiej reprezentującego wspólnotę, wskazane jest jemu powierzyć zadanie przewodniczenia. Należy przy tym zauważyć, że nie jest jasno ukazany sposób realizacji wspomnianej posługi diakońskiej. Diakon jest określany jako „pomagający” biskupowi i prezbiterowi. Termin ten można uznać za ograniczający posługę diakona, albowiem podkreśla jedynie tylko jeden jej aspekt, jakim jest „asystowanie” biskupowi lub prezbiterowi w wypełnianiu jego zadania. Z drugiej strony, to samo Wprowadzenie wskazuje na diakona jako na osobę mającą „,prawo i obowiązek błogosławienia”, ponieważ jest on ,sługą Słowa, ołtarza i miłości”. ${ }^{46}$

Według E. Petrolino, ${ }^{147}$ diakon może przewodniczyć czterem rodzajom celebracji błogosławieństw, wynikającym ze struktury jego szczególnej misji. Są to celebracje błogosławieństw związanych z katechizacją, liturgią, posługą miłości, środowiskiem społecznym i rodziną.

${ }^{144} \mathrm{KL}$, nr 60; por. KPK, kan. 1166, 1168; KKK 1667; T. R i n c ó n - Pé r e z, El orden de los clérigos o ministros sagrados, s. 347; R. S e l e j d a k, Tożsamość, duchowość, formacja i postuga diakonów stałych, s. 125; t e n ż e, Diakonat stały w świetle dokumentów Soboru Watykańskiego II, posoborowego Urzędu Nauczycielskiego Kościoła i narodowych „, Rationes institutionis diaconorum permenentium”, s. 319.

${ }^{145}$ Obrzędy błogosławieństw, t. 1, Katowice 1994, nr 18.

${ }^{146}$ Por. tamże; por. E. P e t r o l i n o, Diakoni, zwiastuni Stowa Bożego, szafarze ołtarza i miłosierdzia, s. 63; R. S e l e j d a k, Tożsamość, duchowość, formacja i posługa diakonów stałych, s. 126; t e n ż e, Diakonat stały w świetle dokumentów Soboru Watykańskiego II, posoborowego Urzędu Nauczycielskiego Kościoła i narodowych „Rationes institutionis diaconorum permenentium”, s. 320.

${ }^{147}$ Por. E. P e tr ol i n o, Diakoni, zwiastuni Słowa Bożego, szafarze ołtarza i miłosierdzia, s. 64. 


\section{Celebracja błogosławieństwa związanego z katechizacja}

Błogosławieństwo związane z katechizacją stanowi pierwszy rodzaj błogosławieństwa celebrowanego przez diakona. ${ }^{148}$ Jest to błogosławieństwo osób zaangażowanych oficjalnie w katechizację powierzoną przez Kościół. Diakon wypowiadający słowa modlitwy błogosławieństwa staje się żywym świadectwem dla współpracowników w katechizacji, że uczestniczy w wyraźny sposób w misji ewangelizacyjnej Kościoła, jako kwalifikowany szafarz słowa, uświęcony sakramentalnie, ale nie wyłączony ze swojej rodziny, środowiska ani ze swej pracy świeckiej. Jako pierwszy animator katechizacji zobowiązany jest on do przygotowania katechetycznego kandydatów do sakramentów, rodziców, chrzestnych i świadków bierzmowania. Wiarygodne głoszenie słowa Bożego stanowi też dla diakona wyzwanie do pełnienia posługi katechetycznej wobec osób w podeszłym wieku, chorych, cierpiących, upośledzonych i religijnie obojętnych. ${ }^{149}$

\section{Celebracja błogosławieństw miejsc i rzeczy do użytku w liturgii albo dla kultu chrześcijańskiego i pobożności ludowej}

Księga Obrzędy błogosławieństw wskazuje, że do diakona należy również celebracja błogosławieństw miejsc i rzeczy do użytku w liturgii albo dla kultu chrześcijańskiego oraz pobożności ludowej. ${ }^{150}$

${ }^{148}$ Por. Obrzędy błogosławieństw, t. 1, cz. 1, rozdz. 4: Obrzędy błogosławieństwa związane z katechizacją i wspólną modlitwą - I. Obrzęd błogosławieństwa katechetów (nr 361-377); Obrzęd błogosławieństwa uczestników katechizacji lub wspólnej modlitwy (nr 378-387).

149 Por. E. P e trol i n o, Diakoni, zwiastuni Słowa Bożego, szafarze ołtarza i miłosierdzia, s. 65; R. S e le j d a k, Tożsamość, duchowość, formacja i postuga diakonów stałych, s. 126, 127; t e n ż e, Diakonat stały w świetle dokumentów Soboru Watykańskiego II, posoborowego Urzędu Nauczycielskiego Kościoła i narodowych „,Rationes institutionis diaconorum permenentium”, s. 320.

${ }^{150}$ Por. Obrzędy błogosławieństw, t. 2, cz. 3, rozdz. 33: Obrzęd błogosławieństwa wody poza mszą św. (nr 1085-1096); cz. 4, rozdz. 36: Obrzęd błogosławieństwa 
Ścisły związek diakona z liturgią potwierdzają zwłaszcza błogosławieństwa przedmiotów kultu i wody święconej. Wprowadzenie do księgi Obrzędy błogosławieństw zaleca, by niektóre przedmioty przeznaczone do kultu, zanim zacznie się ich używać, były pobłogosławione. ${ }^{151}$ Zalicza się do nich puszkę, monstrancję, szaty nakładane przez szafarzy do sprawowania świętej liturgii, a także bieliznę ołtarzową, taką jak korporał i obrusy, których używa się podczas celebracji liturgicznych. ${ }^{152}$

Zaleca się także, by wspomniane przedmioty, nawet jeśli są skromne i proste, były godne, estetyczne i piękne. Tak więc przez posługę liturgiczną diakona błogosławieństwa przyjmują właściwy sobie wymiar egzystencjalny, ponieważ dokonuje się nieustanne przechodzenie od życia liturgicznego do życia świeckiego i odwrotnie, co przekształca liturgię obrzędowości w liturgię życia. ${ }^{153}$

Diakon może także przewodniczyć celebracjom błogosławieństw związanych w szczególny sposób z pobożnością ludową. Celebrując je, winien troszczyć się, by pozostawały one zawsze w harmonii z prawem i duchem liturgii. ${ }^{154}$ Diakon, będąc uprawniony do przewodniczenia wspomnianym celebracjom błogosławieństw, powinien uważać, by nie popierać i nie umacniać jedynie uczuciowości

pokarmów i napojów lub innych przedmiotów wyrażających pobożność (nr 1139-1161); rozdz. 37: Obrzęd błogosławieństwa dewocjonaliów (nr 1162--1182); rozdz. 38: Obrzęd błogosławieństwa różańca (nr 1183-1207); cz. 6, rozdz. 61: Obrzęd błogosławieństwa lampek, zniczy i kwiatów na groby - 1 lub 2 listopada (nr 1430-1432); rozdz. 62: Obrzęd błogosławieństwa krzyża nagrobnego lub nagrobka 2 listopada lub w innym dniu (nr 1433-1438).

${ }^{151}$ Por. tamże, t. 2, nr 1068.

${ }_{152}$ Por. tamze, nr 1070.

${ }_{153}$ Por. E. P e trol i n o, Diakoni, zwiastuni Słowa Bożego, szafarze ołtarza i miłosierdzia, s. 67; R. S e l e j d a k, Tożsamość, duchowość, formacja i postuga diakonów statych, s. 128; t e n ż e, Diakonat stały w świetle dokumentów Soboru Watykańskiego II, posoborowego Urzędu Nauczycielskiego Kościoła i narodowych „Rationes institutionis diaconorum permenentiu”, s. 321.

154 Por. Obrzędy błogosławieństw, t. 2, nr 1139. 
pobożnościowej wiernych i nie sprzyjać wymiarowi ludowemu i teatralnemu liturgii. ${ }^{155}$

\section{Celebracja błogosławieństw przywołujacych postugę miłości}

Ponadto diakon jest wezwany do przewodniczenia niektórym celebracjom błogosławieństw, przywołującym w sposób szczególny posługę miłości wobec chorych. ${ }^{156}$ Istnieje bowiem ,starożytny zwyczaj, mający swe źródło w postępowaniu Chrystusa i Apostołów, że słudzy Kościoła udzielają chorym błogosławieństwa". ${ }^{157}$ Diakon, przewodnicząc celebracjom błogosławieństw związanych z chorymi, daje świadectwo, że chorzy potrzebują siły modlitwy i sakramentów wiary w celu przywrócenia chrześcijańskiego sensu cierpienia, a włączając się w mękę Pańską, przyczyniają się do dobra Kościoła i zbawienia świata. ${ }^{158}$

Zdaniem E. Petrolino, diakon przez tę posługę lepiej ukazuje oblicze Kościoła jako znaku miłości Boga. ${ }^{159}$

155 Por. E. P e trol i n o, Diakoni, zwiastuni Słowa Bożego, szafarze ottarza i miłosierdzia, s. 67; R. S e le j d a k, Tożsamość, duchowość, formacja i posługa diakonów stałych, s. 128; t e n ż e, Diakonat stały w świetle dokumentów Soboru Watykańskiego II, posoborowego Urzędu Nauczycielskiego Kościoła i narodowych „Rationes institutionis diaconorum permenentium”, s. 321.

${ }^{156}$ Por. Obrzędy błogosławieństw, t. 1, cz. 1, rozdz. 1: Obrzędy błogosławieństwa rodzin i ich członków - VIII. Obrzęd błogosławieństwa starców pozostających w domu (nr 258-289); rozdz. 2: Obrzęd błogosławieństwa chorych (nr 290-320); cz. 2, rozdz. 14: Obrzęd błogosławieństwa nowego szpitala lub przychodni dla chorych albo gabinetu lekarskiego (nr 582-598); t. 2, cz. 6, rozdz. 81: Obrzęd błogosławieństwa sprzętu pogotowia ratunkowego (nr 1676-1685); rozdz. 82: Obrzęd błogosławieństwa aparatury medycznej (nr 1686-1698).

157 Tamże, t. 1, nr 290.

${ }^{158}$ Por. E. P e troli n o, Diakoni, zwiastuni Słowa Bożego, szafarze ołtarza i miłosierdzia, s. 67.

159 Por. tamże, s. 68. 


\section{Celebracja błogosławieństw zwiąanych ze środowiskiem społecznym i rodzina}

Księga Obrzędy błogosławieństw zawiera ryty celebracji błogosławieństw domów, miejsc pracy, urządzeń i narzędzi technicznych. ${ }^{160}$ Diakon, celebrując te błogosławieństwa, wchodzi w różne środowiska społeczne. Stając wobec wydarzeń życia codziennego, uwidacznia obecność Boga, który winien być uwielbiony i któremu należy składać dziękczynienie za znaki Jego dobroci w każdej sytuacji ludzkiego życia. ${ }^{161}$

Trzeba też podkreślić, że wspomniane celebracje błogosławieństw, dotyczące wielorakiej aktywności ludzkiej, mają duże znaczenie dla życia chrześcijan. ${ }^{162}$ Pozwalają one bowiem zrozumieć lepiej posłannictwo Kościoła oraz relację zachodzącą między środowiskami społecznymi a środowiskiem kościelnym, w którym jest osadzona posługa diakona. Nawet jeśli zazwyczaj obowiązkiem diakona nie jest chrześcijańskie animowanie rzeczywistości doczesnych czy środowisk pracy, „,w których ludzie podejmują stałą pracę dla własnego dobra i dla dobra innych" ${ }^{163}$ będzie on mógł zebrać doświadczenia i oczekiwania tych, których spotka, i uczynić je swoimi oraz wspólnoty kościelnej.

Innym obszarem celebracji błogosławieństw przez diakona jest wspólnota rodzinna. Kościół, ze względu na ogromny szacunek okazywany rodzinie jako wspólnocie życia i miłości małżeńskiej, chcianej przez Pana, ${ }^{164}$,ustanowił pewne sakramentalia, dzięki którym w określonych okolicznościach życie rodzinne może być ubogacone przez głoszenie Słowa Bożego i przez szczególne błogosławieństwo". ${ }^{165} \mathrm{~W}$ ten sposób podkreśla się też cenny wkład

\footnotetext{
${ }^{160}$ Por. Obrzędy błogosławieństw, t. 1, cz. 2.

${ }^{161}$ Por. tamze, nr 453 i 455.

162 Por. tamże, nr 454.

163 Tamże, nr 599.

164 Por. tamże, nr 40.

165 Tamże, nr 41.
} 
diakonów żonatych w pełnienie ich posługi wraz $\mathrm{z}$ rodzinami i dla rodzin, ${ }^{166}$ nie tylko $\mathrm{w}$ odniesieniu do zagadnień moralnych i liturgicznych, ale również o charakterze osobistym i społecznym życia małżeńskiego i rodzinnego. ${ }^{167}$

W tym kontekście należy przypomnieć, że Ojciec Święty Jan Paweł II uważa diakonów za najbliższych współpracowników biskupa, zaraz po prezbiterach, w duszpasterstwie rodzin. Papież podkreśla, że diakon, podobnie jak kapłan, „winien zawsze odnosić się do rodzin jak ojciec, brat, pasterz i nauczyciel". ${ }^{168}$

\section{Obrzędy pogrzebowe}

Diakon może też przewodniczyć nabożeństwom żałobnym odprawianym bez mszy św. oraz obrzędowi pogrzebu i pochówku. ${ }^{169}$

166 Por. tamże, cz. 1, rozdz. 1: Obrzędy błogosławieństwa rodzin i ich członków I. Obrzęd błogosławieństwa rodziny (nr 42-67); II. Doroczne błogosławieństwo rodzin w ich domach (nr 68-89); III. Obrzedy błogosławieństwa małżonków (nr 90-134); IV. Obrzędy błogosławieństwa dzieci (nr 135-173); V. Błogosławieństwo synów lub córek (nr 174-194); Obrzęd błogosławieństwa narzeczonych (nr 195-214); VII. Obrzędy błogosławieństwa kobiety przed i po urodzeniu dziecka (nr 215-257); por. E. P e t r o 1 i n o, Diakoni, zwiastuni Stowa Bożego, szafarze ottarza i miłosierdzia, s. 70; R. S e 1 e j d a k, Diakonat stały w świetle dokumentów Soboru Watykańskiego II, posoborowego Urzędu Nauczycielskiego Kościoła i narodowych „Rationes institutionis diaconorum permenentium”, s. 323.

${ }^{167}$ Por. Obrzędy błogosławieństw, t. 1, nr 74.

168 J a n P a w e 1 II, Adhortacja apostolska „Familiaris consortio”, nr 73.

169 Por. KK, nr 29; P a w e 1 VI, Motu proprio „Sacrum diaconatus ordinem”, V, 22, 5, s. 702; Kongregacja ds. Duchowieństwa, Papieska Rada ds. Świeckich, Kongregacja Nauki Wiary, Kongregacja ds. Kultu Bożego i Dyscypliny Sakramentów, Kongregacja ds. Biskupów, Kongregacja ds. Ewangelizacji Narodów, Kongregacja ds. Instytutów Życia Konsekrowanego i Stowarzyszeń Życia Apostolskiego, Papieska Rada ds. Interpretacji Te k s tó w P r a w n c h, Istruzione su alcune questioni circa la collaborazione dei fedeli laici al ministero dei sacerdoti „Ecclesiae de mysterio”, art. 12, s. 599-601; DPŻDS, nr 36; T. R i n c ó n - P é r e z, El orden de los clérigos o ministros sagrados, s. 347; R. S e le j d a k, Diakonat staty w świetle dokumentów Soboru Watykańskiego II, posoborowego Urzędu Nauczycielskiego Kościoła i narodowych „,Rationes institutionis diaconorum permenentium”, s. 323. 
W przypadku jednak, gdy kapłan jest obecny i dyspozycyjny, to właśnie jemu należy powierzyć funkcje przewodniczenia. ${ }^{170}$

Diakon, by móc właściwie wypełnić wspomnianą posługę, w zależności od konkretnych sytuacji czy też życzeń krewnych zmarłego, winien być obeznany z różnymi możliwościami celebracji tej posługi, proponowanymi przez rytuał Obrzędu pogrzebu. ${ }^{171}$

Podsumowując, należy zauważyć, że posługa liturgiczna diakonów stałych, wypływająca z sakramentu święceń, różni się zarówno od posługi liturgicznej kapłańskiej, jak i wiernych, nie mających święceń. W czasach współczesnych posługa ta stanowi najważniejszą diakonię diakonów stałych w Kościele. Diakoni, sprawując ją, są wezwani do wiernego przestrzegania obowiązujących przepisów liturgicznych. Nie mogą z własnej inicjatywy niczego dodawać, pomijać lub zmieniać. Ponadto diakoni, wykonując posługę liturgiczną w ścisłej łączności z biskupem i kapłanami, powinni być świadomi, że „każda celebracja liturgiczna, jako działanie Chrystusa-Kapłana i Jego Ciała, czyli Kościoła, jest czynnością w najwyższym stopniu świętą"172 i dlatego winni ją sprawować w duchu pokory. Jednocześnie ma ona skłaniać ich do świętości życia oraz do tego, by starać się być jej godnym.

ks. Ryszard SELEJDAK

${ }^{170}$ Por. Obrzędy błogosławieństw, t. 1, nr 18; DPŻDS, nr 36.

${ }^{171}$ Por. Obrzędy pogrzebu, Katowice 2001, nr 23-25.

$172 \mathrm{KL}, \mathrm{nr} 7$. 